\title{
Late Neogene and Quaternary Vertical Motions in the Otway Coast, Southeast Australia (II): Epeirogenic Uplift Driven by Lithospheric Flexural Deformation
}

Jaeryul Shin*

Department of Geography, Kyungpook National University, Daegu 701-702, Korea

\section{호주 남동부 Otway 해안의 후기 신제3기 및 제4기 융기 운동(II): 암석권 휨 현상에 의한 대륙 지각의 융기}

\author{
신 재 열* \\ 경북대학교 지리학과, 702-701, 대구광역시 북구 대학로 80
}

\begin{abstract}
The relationship between tectonic uplift and geophysical analysis of gravity anomalies and the in-situ stress fields in the Otway Ranges, SE Australia is addressed in this study to understand the nature and possible mechanism for the neotectonic movements. The uplift axis of the ranges is coincident with the regional Bouguer gravity highs whereas thick Tertiary sedimentary successions are highly correlated with the gravity lows along the basin rift geometry. This result suggests that the gravity highs are separated by the thick Tertiary sedimentary successions. Regional structural trends associated with faults and foldings of the deformed surfaces are consistent with the prevailing NW-SE $\mathrm{S}_{\mathrm{Hmax}}$ trend in this part of the continent. The anomalously positive correlation between topography and Bouguer gravity fields suggests possibly a lithospheric flexural deformation mode at a long wavelength (order of $10^{2} \mathrm{kms}$ ) in the region. It also suggests that the reactivation of pre-existing lithospheric structures driven by plate boundary forces plays a key role in this mode.
\end{abstract}

Keywords: epeirogenic uplift, gravity anomaly, in-situ stress field, lithospheric flexure, the Otway Ranges

요 약: 본 연구는 호주 남동부 지역 Otway 산맥 일대에서 확인되는 신기 지체구조 운동의 성격과 매커니즘을 규명하 기 위해 현상적 융기 패턴과 중력이상 및 현생 응력 체계 등의 지구물리 자료간의 상관관계를 분석하였다. Otway 산맥 의 융기축은 높은 중력값을 보이는 지역과 일치하는 반면 주변의 두꺼운 제 3 기 퇴적층 지역은 낮은 중력값을 보이는 지역과 일치하고 있어 높은 중력값의 이상 구간은 제3기 퇴적층 지역에 의해 구분되는 형태를 보여주고 있다. 한편 단 층, 습곡 활동으로 특징되는 연구 지역 일대의 지질 구조 및 분포 패턴은 호주 남동부 지역의 현생 응력 체계와 잘 일 치한다. 지형 고도와 중력 간의 양의 상관관계는 가설적으로 연구 지역 일대의 융기 운동이 대규모 $\left(10^{2} \mathrm{~km}\right.$ 대 $)$ 의 암석 권 휨 현상에 의해 발생하고 있음을 보여주고 있으며, 판 경계 응력에 의한 암석권 내 기존 약대들의 재활성화는 이러 한 대규모 변형 양식에 있어 중요한 역할을 담당하고 있는 것으로 판단된다.

주요어: 조륙 운동, 중력이상, 현생 응력 체계, 암석권 휨 현상, Otway 산맥

\section{Introduction}

Recent advances in plate tectonics have provided an understanding of many aspects of the horizontal lithospheric plate movements and potentially provide

*Corresponding author: jaeryul.shin@gmail.com Tel: +82-53-950-5227

Fax: +82-53-950-6227 important insights into the dynamics of the hot interior of the planet. However, it is still a challenge to explain the vertical motions of the Earth's surface, especially in intraplate settings. Such vertical movements may arise from a variety of causes relating to a largescale dynamics in mantle flows and lithospheric responses to plate boundary forces well understood in terms of plate tectonics (Beekman et al., 1996; Celerier et al., 2005; Sandiford and Quigley, 2009). 


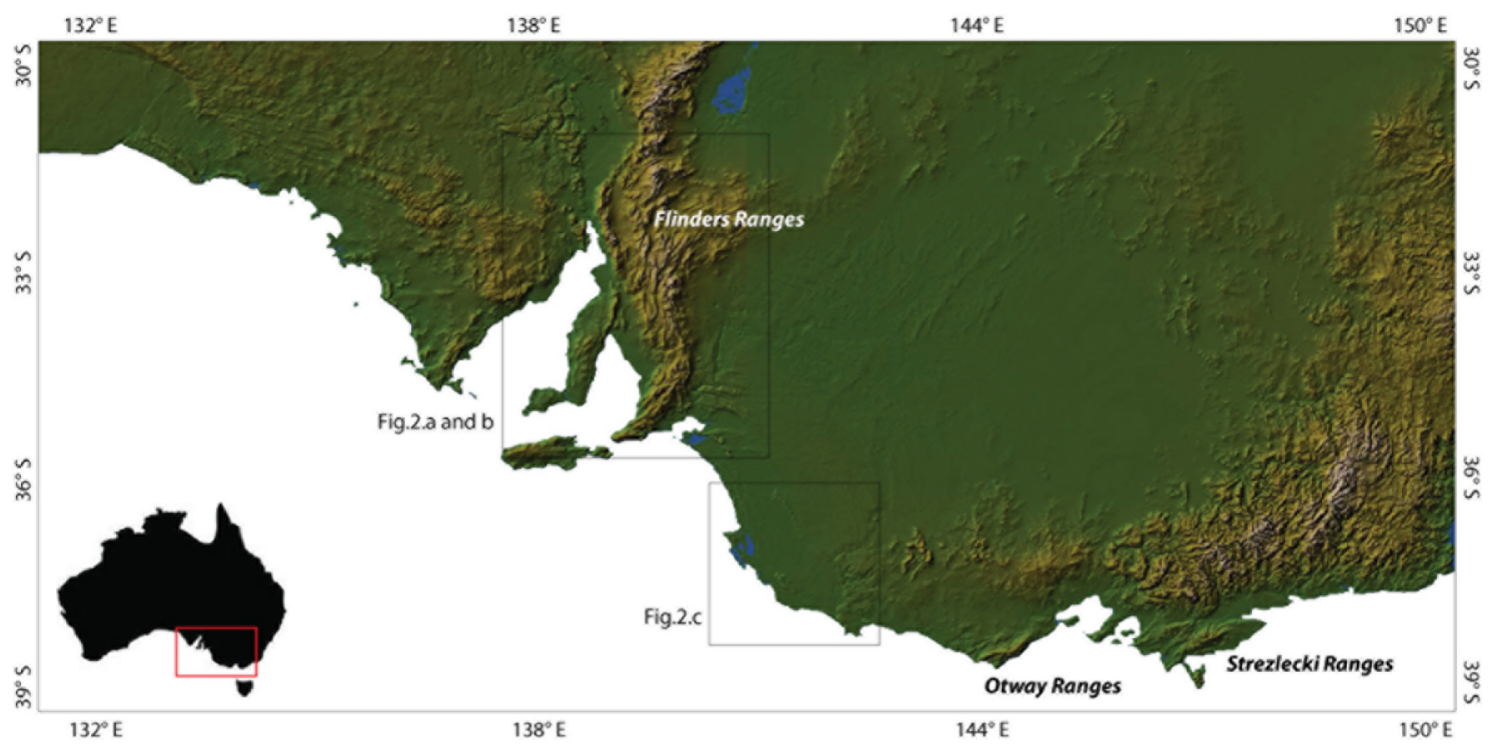

Fig. 1. Shaded relief of South Australia derived from the SRTM 3 arcsecond digital elevation data. Numbers refer to Figures of associated localities.

As described in the previous study (Shin, 2012), the ongoing deformation in the Otway Ranges correlates with mild tectonic activity across a much broader region in Southern Australia (Fig. 1). For example, in South Australia, the Flinders Range is bounded by a set of scarps associated with active bounding faults with cumulative late Neogene displaces in excess of 100 meters (Sandiford, 2003b; Quigley et al., 2006) (Fig. 2a). Also, the Quaternary shorelines along its southern flank on the Gambier Plain in South Australia indicates significant amount of uplift from the middle Quaternary (Huntley et al., 1993) (Fig. 2b).

This series of the studies including Shin (2012) for a neotectonic context during the past $5 \mathrm{Ma}$ for the Otway Ranges along the southern Victoria coast, SE Australia evaluate the extent to which mild intraplate tectonism has the capability to influence the geomorphic evolution of continental interiors by evaluating the development of marine terraces along the mountainous coastal area and stratigraphic relationship between the Quaternary marine terraces and Pliocene strandlines. As a result of Shin (2012), seven marine terraces elevated up to $220 \mathrm{~m}$ apsl have been mapped along the Otway coasts, and the numerical formation age of the T-2 terrace at $12 \mathrm{~m}$ apsl has been assigned as MIS
7 stage using OSL dating method. The calculated uplift rate during the late Quaternary is $56.6 \pm 6.6 \mathrm{~m}$ $\mathrm{Myr}^{-1}$, and the higher terraces above the $\mathrm{T}-2$ are assigned in time of the early Pleistocene with assumption of a constant uplift during the Quaternary. The study also suggested an intensified tectonic response around at the boundary between Quaternary and Pliocene derived from the stratigraphic relationship between the paleo-shoreline records.

The mode of active deformation in South Australia (i.e. Flinders Range) fits well with a wavelength deformation of order $10^{2} \mathrm{kms}$, which is comparable to the thickness of the lithosphere deviations from local isostasy. Such wavelength undulations of the Earth's surface can usually be related to flexural strength of the lithosphere (Burov et al., 1993; Beekman et al., 1996; Gerbault, 2000; Cloetingh et al., 2002; Sandiford et al., 2009). Celerier et al. (2005) have suggested that the long wavelength pattern of deformation associated with the Flinders Range and surrounding basins could be understood in terms of lithospheric flexural mode. This interpretation has been, in part, derived from the observed positive coherence between topography and gravity fields, as well as regional structural trends on deformed surfaces. 

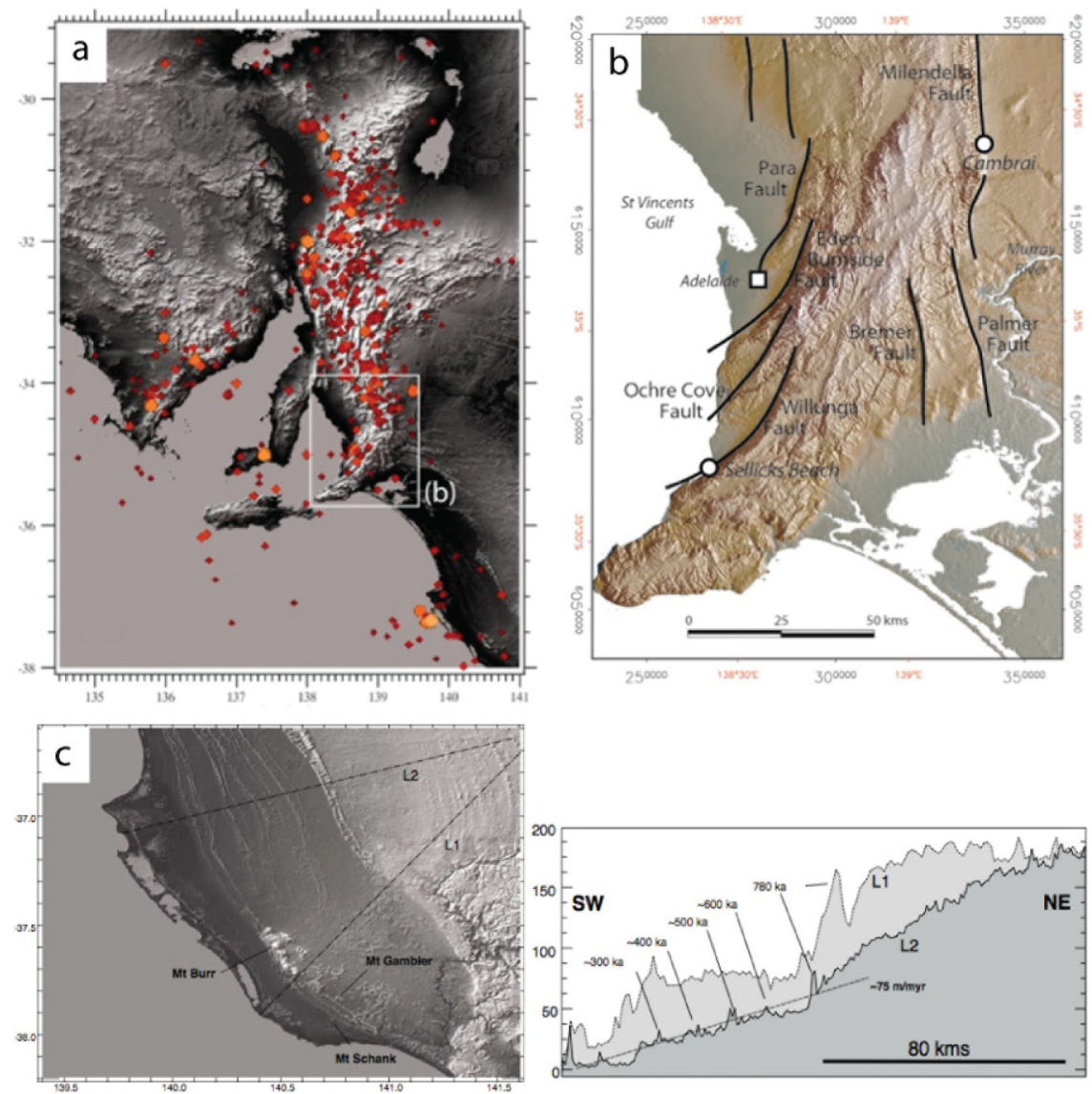

Fig. 2. (a) Seismicity map of the Flinders Ranges and (b) Shaded relief image of the Mt Lofty Ranges and Fleurieu Peninsula, South Australia, showing the main Quaternary faults (solid lines) (Sandiford and Quigley, 2009). (c) Shaded relief image of a portion of the Murray Basin, showing Quaternary beach ridges on the Gambier Plain. The age structure of shoreline features indicate significant amount of uplift in the region (>75 m/Myr) over the $780 \mathrm{kyrs}$ (Sandiford et al., 2009).

The up-down motion in lithospheric flexure is described by stretching of the lithosphere and subsequent upwelling by isostatic compensation between the lithosphere and the asthenosphere. Possible causes vary for example, localized isostasy, a set of faulting in the lithosphere, convecting anomalously hot mantle, and igneous material injection like a mantle plume (Sutherland, 2003; Demidjuk et al., 2007).

Herein, this study provides geophysical analyses such as gravity anomaly, tectonic structure and in-situ stress field to explain the nature and possible mechanism for the neotectonic movements in the Otway Ranges, SE Australia.

\section{Origin of the Otway Ranges and tectonic structure}

The Otway Basin was formed along the southern margin of the continent during the Early Cretaceous rifting associated with the separation of Australia and Antarctica (Finlayson et al., 1996; Gurnis et al., 1998; Cande and Stock, 2004). The Otway Ranges is the inverted Cretaceous rift sequence in the onshore part of the basin (Fig. 3). The formation of the ranges has been interpreted to have commenced since the Eocene just after the rapid separation and the formation of Australia-Antarctic ocean ridge associated with the 


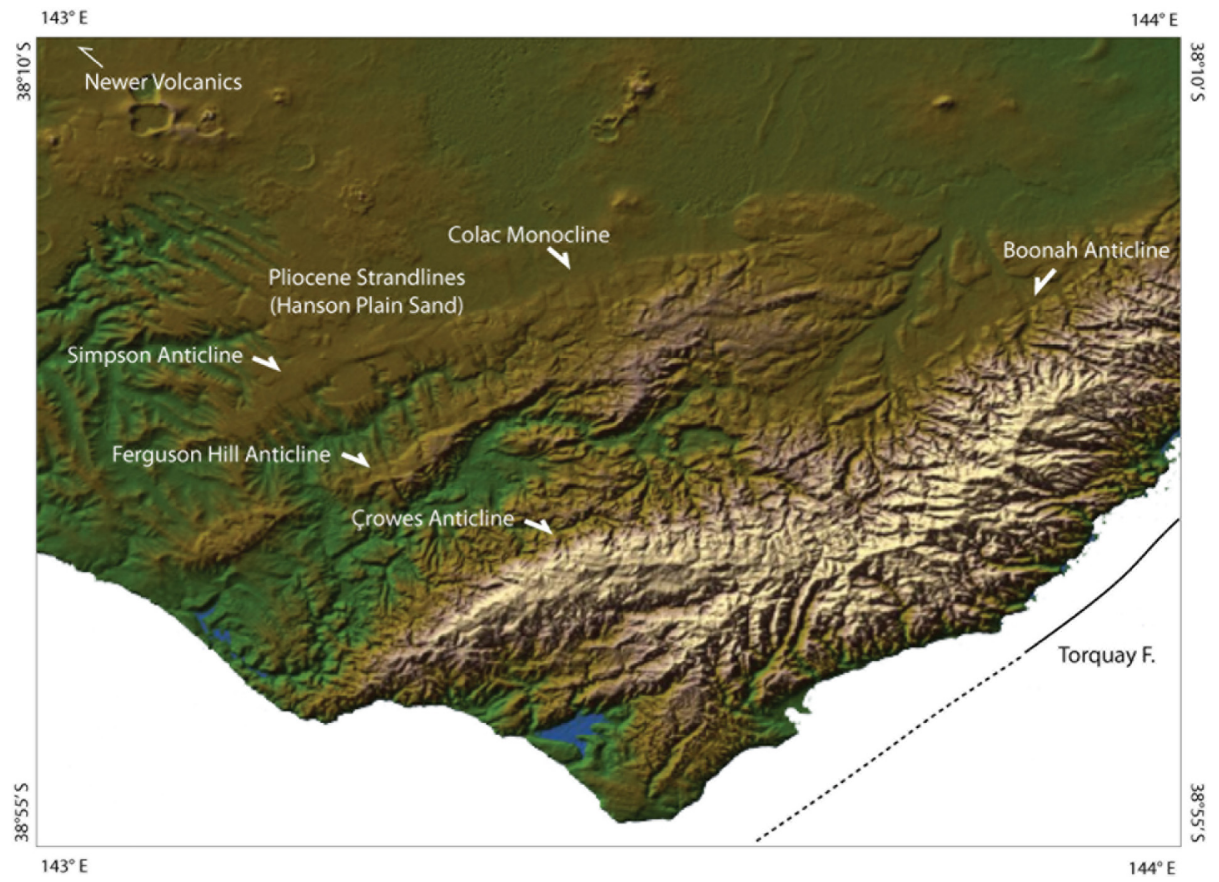

Fig. 3. Shaded topography of the Otway Ranges with the locations of the major tectonic and geomorphic elements.

onset of fast northward moving of the Australian continent at about 43 Ma (Dyksterhuis and Müller, 2008). Reactivation of pre-existing structures initiated in the Middle Eocene probably played a role in localising the uplift (Tickell et al., 1992). Although uplift continued with minor intensity throughout the entire Tertiary, there is clear evidence for significant uplift since the Pliocene. The early Pliocene-age Hanson Plain Sand unconformably overlies Cretaceous to Late Miocene strata (i.e. the Heytesbury Group, Wangerrip Group and Port Campbell Limestone farther to northwest) along the northwestern flanks of the ranges (Abele, 1995; Wallace et al., 2005) (Table 1 ), and is characterised by a distinctive rectilinear drainage network incised into a gently tilted and fault disrupted surface (Hanson Plain Sands). The Hanson Plain Sands rise from about $120 \mathrm{~m}$ above sea level in the northwest to $280 \mathrm{~m}$ in the southeast (Sandiford, 2003a). Furthermore, offshore seismic data in the Otway Basin south of the ranges show inverted halfgraben and graben geometries folded along an ENEtrending axis. Deformed Pliocene strata at a shallow depth imply that uplift continued through the Pliocene.
Extensive alluvial deposits along the northeastern and the northwestern corners of the ranges are gently tilted toward west.

In the vicinity of the Otway Ranges, there are a number of basement structures along the paleo-rift geometry of the Otway Basin. The Simpson Anticline was mapped from outcrop and seismic information (Tickell et al., 1992), which is considered as a Late Tertiary structure. This feature appears to be formed between northwesterly dipping fault of the Colac Monocline and its southeasterly dipping splay fault. The Fergusons Hill Anticline is recognized from surface geology and topographic expression as well as an elongated gravity high formed an emergent structure in the Middle Eocene (Abele, 1995; Sandiford, 2003a). The Hanson Plain Sands dated as Pliocene age (Wallace et al., 2005) is broadly folded along a $\mathrm{NE}$ trending axis, indicating that uplift of the range continued to the Pliocene (Fig. 4). The Torquay Fault, which is the main southeastern boundary structure of the Otway Ranges, runs parallel to the southern coastline in several kms offshore. The fault plane appears to dip to the northwest with bedrock 
Table 1. Generalised chronostratigraphy of the Otway Basin, Southern Victoria from Finlayson et al. (1996) and Australian Stratigraphic Units Database

\begin{tabular}{|c|c|c|c|c|}
\hline Age (Ma) & Epoch & Victoria & Group & Description \\
\hline & Quaternary & Newer Volcanics & & Tholeiitic to minor alkaline and basanitic lavas \\
\hline & Pliocene & Hanson Plain Sand & & Previously Moorarbool Viaduct Formation \\
\hline \multirow{4}{*}{25} & \multirow[t]{2}{*}{ Miocene } & & & \\
\hline & & Port Campbell Limestone & \multirow{3}{*}{ Heytesbury Group } & \multirow{3}{*}{$\begin{array}{l}\text { Littoral to deep marine } \\
\text { bryozoan carbonates and clastics }\end{array}$} \\
\hline & \multirow{2}{*}{ Oligocene } & Gellibrand Marl & & \\
\hline & & Clifton Fm & & \\
\hline \multirow{2}{*}{50} & Eocene & Demons Bluff Fm & Nirranda Group & $\begin{array}{l}\text { Fine-grained marginal } \\
\text { marine/littoral sediments; marl. }\end{array}$ \\
\hline & \multirow[t]{2}{*}{ Paleocene } & Eastern View Fm & Wangerrip Group & Shallow marine to continental deposits \\
\hline \multirow{5}{*}{75} & & Timboon Sand & \multirow{6}{*}{ Sherbrook Group } & \multirow{6}{*}{ Marine sediments } \\
\hline & \multirow{5}{*}{$\begin{array}{l}\text { Late } \\
\text { Cretaceous }\end{array}$} & Paaratte Fm & & \\
\hline & & Nullawarre Greensand & & \\
\hline & & Belfast Mudstone & & \\
\hline & & Flaxman Fm & & \\
\hline 100 & & Waarre Fm & & \\
\hline
\end{tabular}

downthrown in that direction, and a Late Tertiary reactivation has inverted the fault into a reverse fault which has monoclineally folded Tertiary rocks down to the southeast.

\section{Correlation between gravity and topography}

Global gravity shadow shows that the Earth's topography is supported largely by the isostatic compensation of density anomalies within the lithosphere or by dynamic processes beneath the lithosphere (Karner and Watts, 1983; Smith and Sandwell, 1997). The strength of the lithosphere contributes a short wavelength gravity field (10's-100's $\mathrm{kms}$ ) that the compensation is achieved by thickening of the crust, but differs in taking into account its lateral strength. On the other hand, a long wavelength gravity field (100's-1000's kms) in continents and oceans cannot be attributed to such isostasy instead, maybe directly attributed to density differences in the mantle (Mckenzie et al., 2002). The gravity anomalies in mountains are in general negative because the measured gravity is less than what would be expected from a constant level of density change. The lithosphere, however, isostatically responds to gravitationally surficial loads in manner to an elastic plate overlying a week fluid such as mantle lithosphere (Karner and Watts, 1983). In this case, the gravity anomaly is characterised by a gravity high (positive) over the flexural bulge and a gravity low associated with the basement deformation under the surface load.

The Bouguer gravity field of Southeast Australia and correlations between observed topography and gravity anomalies cross the Otway Ranges are illustrated in Fig. 5 and Fig. 6, respectively. Previously, four gravity highs have been interpreted from the data of the Victorian gravity database (Abele, 1995) in the 


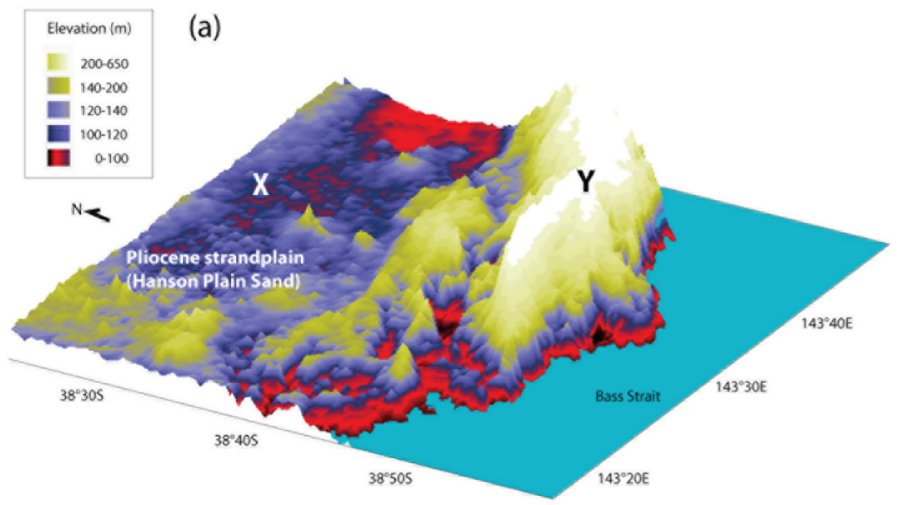

(b)

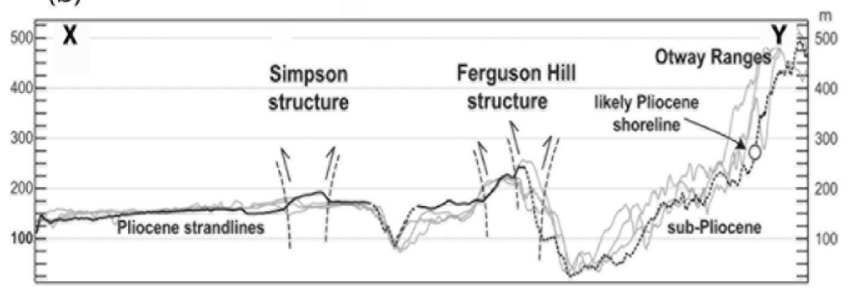

Fig. 4. (a) Three-dimensional topography of the Pliocene strandplains and the Otway Ranges, (b) the suggested position of the Pliocene shoreline on the ancestral range front (modified from Shin, 2012).

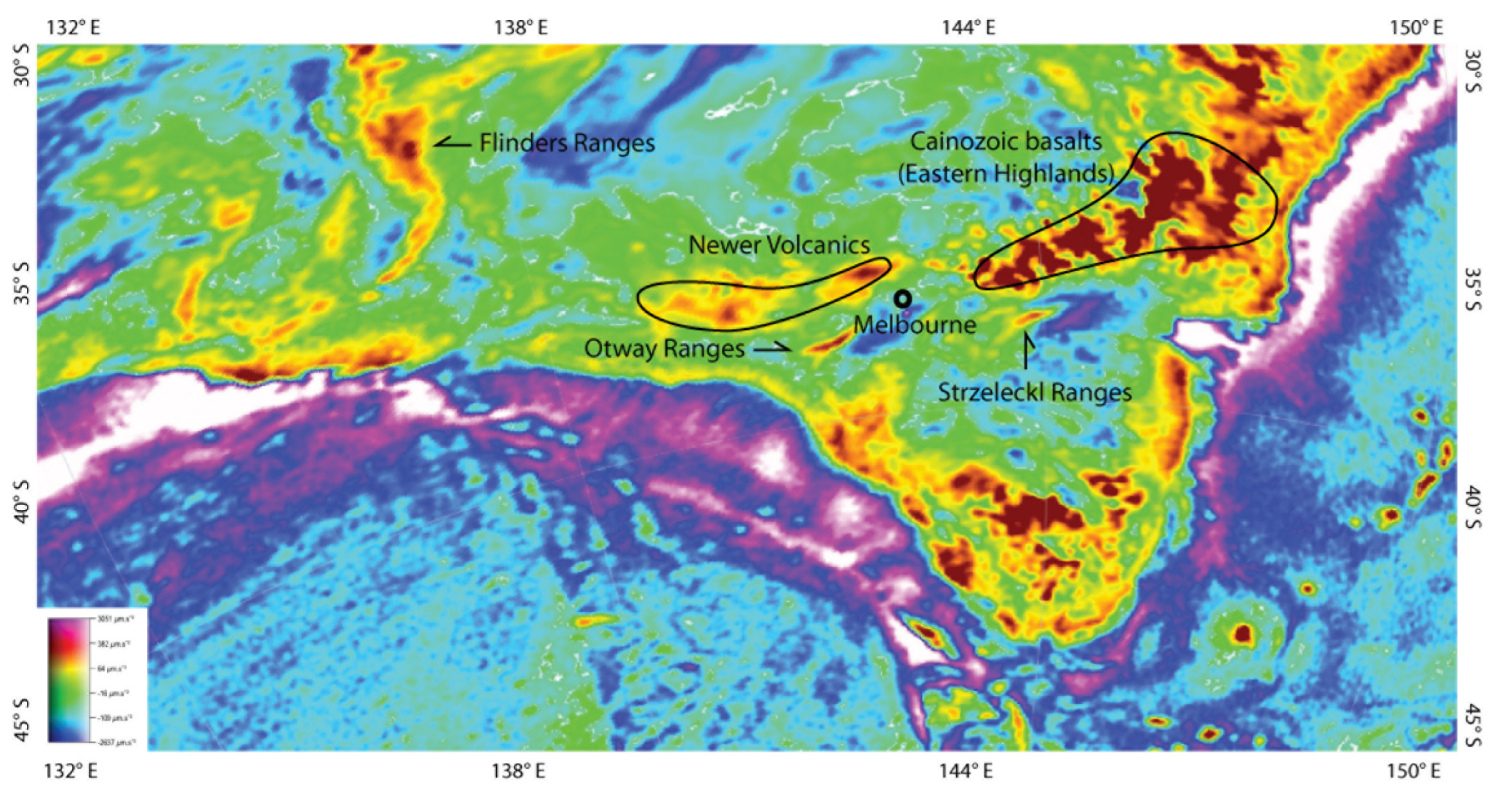

Fig. 5. Bouguer gravity anomaly of SE Australia reproduced from 1-min Gravity anomaly dataset of Smith and Sandwell (1997) using GPlates 1.0.1. Positive relationships between gravity and topography are well expressed in the Otway Ranges and Strzeleckl Ranges in SE Australia, and the Flinders Ranges in South Australia. The centre of the Newer Volcanics (Late Pliocene to Quaternary) is located in the north farther from the Otway Ranges, whereas the uplift increases away from the centre.

eastern Otway Basin. It is clearly seen that the large volume of gravity highs in the Newer Volcanic province, Eastern Highlands and Tasmania (the corner of SE Australia) are associated with activities of magmatism (Fig. 5). However, the centre of the Newer Volcanism (Late Pliocene to Quaternary) is 

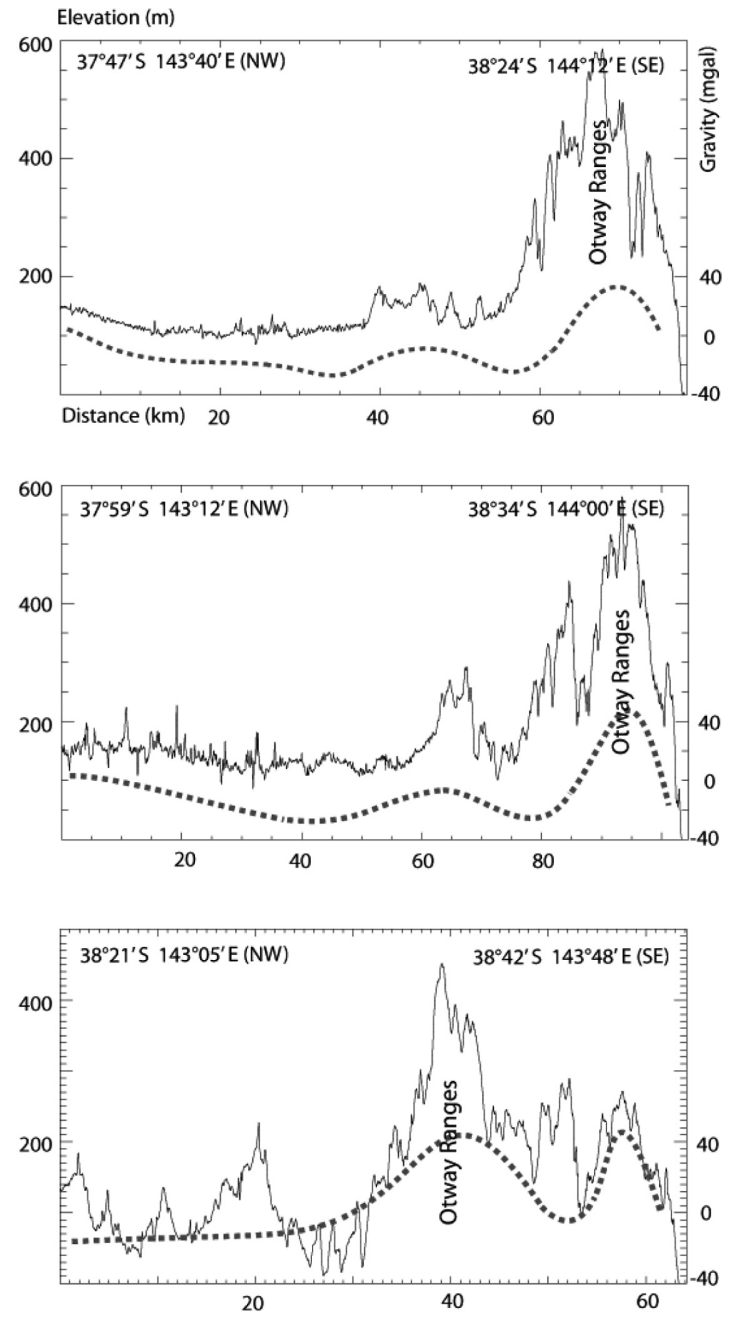

Fig. 6. Positive relationships between Bouguer gravity anomaly derived from Abele (1995) and topography in the Otway Ranges.

located in the north farther from the ranges, and the uplift increases away from the centre. In around the Otway Ranges and the surroundings the gravity highs are typically NNE to NE trends, perpendicular to the basin axis. The series of gravity anomalies coincides with topographic undulation expressed by anticlines and synclines in the northwestern side of the ranges. In particular, the uplifting axis of the Otway Ranges is strongly coincident with a significant positive Bouguer gravity anomaly of amplitude $40 \mathrm{mGal}$, whereas gravity lows correlate with thick sedimentary successions deposited parallel with the range fronts with the depth of $\sim 1500 \mathrm{~m}$ in areas of subdued topography (Fig. 6). For example, the NE trending gravity low along the northern flanks of the range with the amplitude of $-20 \mathrm{mGal}$ relates to a graben structure of Tertiary sediments (i.e. Sherbrook Group, Wangerrip Group, Nirranda Group, Heytesbury Group) bounded by NNE trending faults.

\section{In-situ stress fields in SE Australia}

The in-situ stress field of the south-eastern Australia inferred from earthquake focal mechanisms and borehole breakouts is characterised by large obliquity between the maximum horizontal compressive stress orientation $\left(\mathrm{S}_{\mathrm{Hmax}}\right)$ and the absolute plate motion azimuth, and in the Otway Basin the azimuth of $\mathrm{S}_{\mathrm{Hmax}}$ derived from breakouts is $136 \pm 15^{\circ}$. These NW-SE to E-W $\mathrm{S}_{\mathrm{Hmax}}$ orientations are consistent with a plate boundary force control between the Indo-Australian and the Pacific plates on the intra-plate stress fields (Coblentz et al., 1998; Reynolds et al., 2002; Dyksterhuis and Müller, 2008) (Fig. 7). The stress field stemming from plate driving forces has led brittle deformations in the upper lithosphere. Seismic images of the Otway Basin on-/offshore (Finlayson et al., 1996; Musgrave and Rawlinson, 2010) exhibit undulating basement structures, penetrating to the upper Cretaceous strata (Fig. 8a). The undulations are offset along NE trending axes, compatible with the NW-SE to E-W stress orientations, suggesting that reactivation of pre-existing lithospheric structures driven by plate boundary forces has been a important role for the uplift in the Otway Ranges and the surroundings since the Tertiary in the current tectonic regime. Additionally, kink bands developed in a dune unit, dated ca. $125 \mathrm{ka} \mathrm{BP}$, in the Liptrap Peninsula strongly support that the current plate boundary forces are strained in Southeast Australia throughout the Quaternary (Fig. 8b). The ongoing compressional tectonics across Southeast Australia have been considered as the result of the late Neogene changes in the coupling of the Pacific and Australian plates, coinciding with the building of the Southern Alps in 


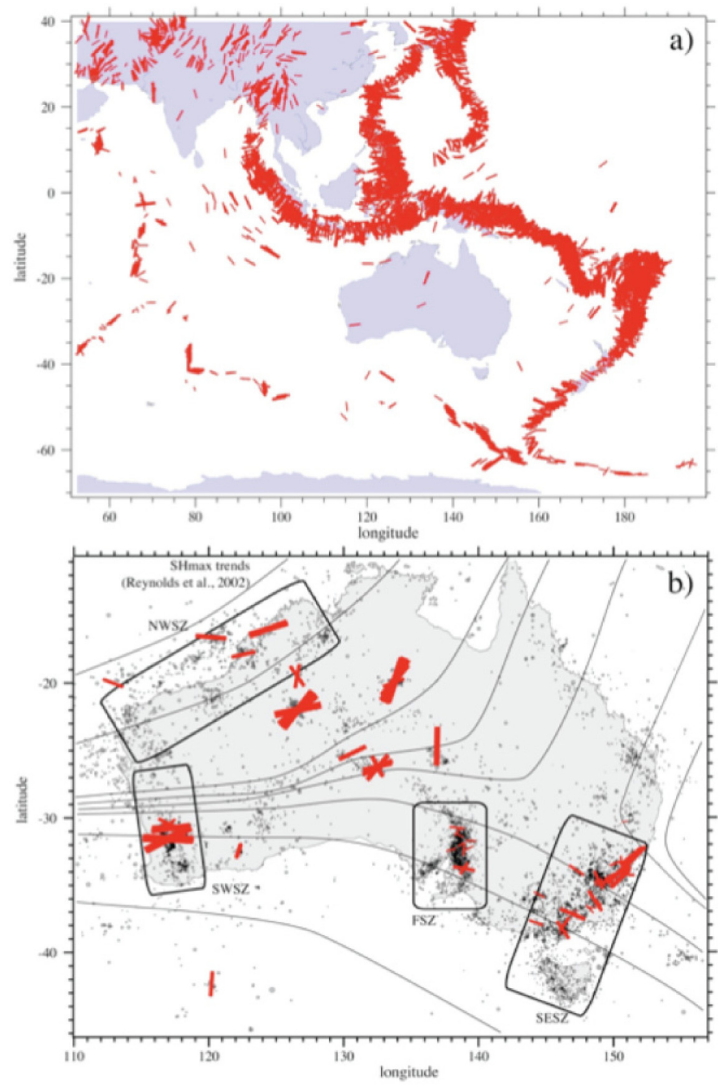

Fig. 7. (a) P-axis trends around the Indo-Australian plate derived from the Harvard CMT database with epicentral depths less than $50 \mathrm{kms}$. (b) Earthquake epicentres from the Geoscience Australian earthquake catalog. P-axis trends for all available focal mechanism solutions, scaled for magnitude of the event. Maximum magnitude events are $\mathrm{Mw}=6.8$ (Sandiford and Quigley, 2009).

New Zealand at between 10 and 6 Ma (Sandiford et al., 2004).

\section{Discussion}

\section{The mode of lithospheric flexural deformation}

At wavelengths in variations in surface elevation comparable to the thickness of the lithosphere deviations (order $10^{2} \mathrm{kms}$ ) from local isostacy can usually be related to flexural strength of the lithosphere, and thus are essentially isostatic in nature (Karner and Watts, 1983; Mckenzie et al., 2002; Sandiford et al., 2009). This lithospheric flexural mode explains vertical movements of the crust, and

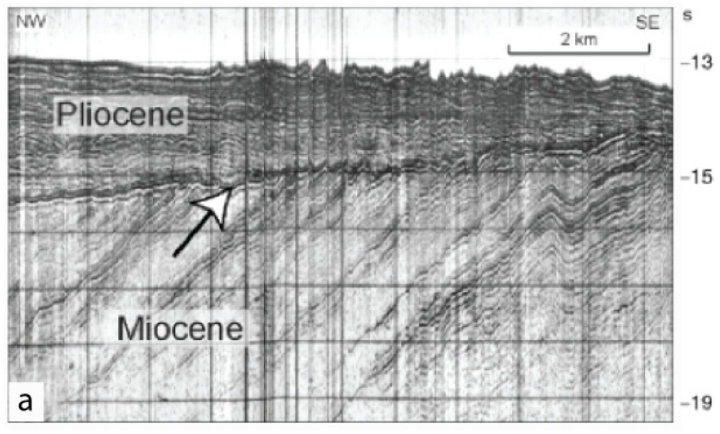

b

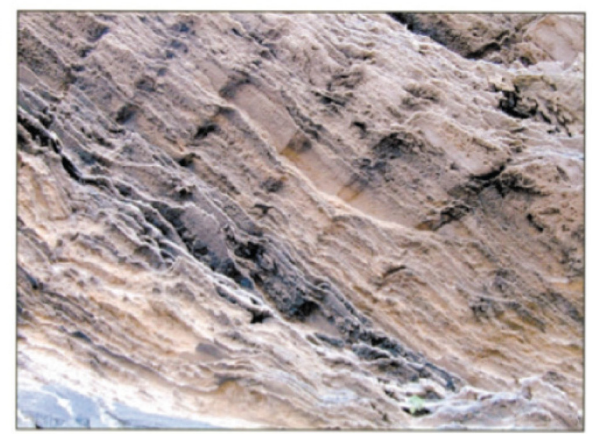

Fig. 8. (a) Shallow offshore seismic section south of the Otway Ranges, showing Miocene-Pliocene unconformity and folding of the underlying Miocene section along a NE trending axis (Sandiford et al., 2004). (b) Kink bands in dune limestone where the western boundary fault of the Liptrap Peninsula, South Gippsland. The dune systems along the southern coast date to last interglacial high sea stand at ca $120 \mathrm{ka}$ BP. Field of view is $\sim 1 \mathrm{~m}$ wide (Sandiford, 2003b).

was recognized first in the Indian Ocean (Beekman et al., 1996; Gerbault, 2000) (Fig. 9). The lithospheric process, particularly associated with intraplate environments out of direct influence of plate margin processes, is driven by regional isostatic compensation between the lithosphere and the asthenosphere. It is assumed that the lithosphere reacts by faulting or flexing solely in response to gravity loadings such as sediments loading and plate motion driving forces (Kearey and Vine, 1996). Beekman et al. (1996) suggested two different scales of tectonic deformation occurring in the central Indian Ocean; whole lithosphere folding with wavelengths varying between 100 and $300 \mathrm{~km}$, and crustal faults with a characteristic spacing of $5 \mathrm{~km}$, both driven by regional intraplate stresses origination from the Indo-Eurasian collision. Substantial compression stresses in the central Indian Ocean 


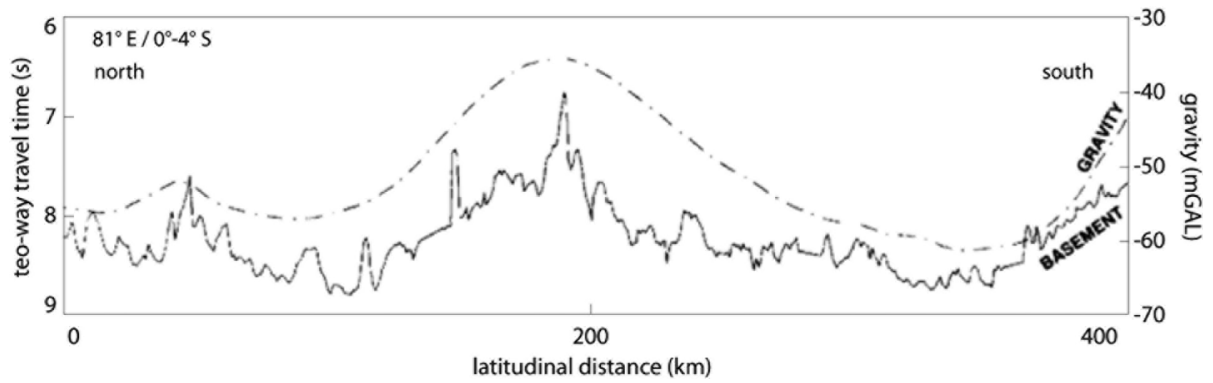

Fig. 9. North-south running profiles of digitized acoustic basement (solid line) and free-air gravity anomaly (dashed line), demonstrating a long wavelength folding (lithospheric flexural dformation) within the central Indian Ocean (modifed from Beekman et al., 1996)

reactivate pre-existing crustal faults, and, in a later phase, initiate folding and buckling of the entire ocean lithosphere. Numerical model (Gerbault, 2000) also demonstrated that lithospheric folding does not develop in the absence of fault reactivation, and not start until horizontal loading has significantly reduced the mechanical strength of the lithosphere.

The vertical motions associated with the Otway Ranges and a surrounding basin such as the western Otway Basin are characterised by the horizontal length of over $100 \mathrm{~km}$ and the amplitude of $>200 \mathrm{~m}$ since the Pliocene that can be compared to the lithosphericscaled deformation. Previously, Celerier et al. (2005) have proposed the deformation mode of Flinders Ranges and surrounding basins as a lithospheric flexure based on the observed positive coherence between topography and gravity and the modeling results. With a similar approach, the deformation with the scale of order $10^{2} \mathrm{kms}$ associated with the Otway Ranges and the low surrounding basin is plausibly interpreted by localised lithospheric flexural mode caused by instabilities along pre-existing geometry within a regional compression stress regime. Significantly thick and dense sediments of Late Cretaceous to Tertiary strata in the Otway Basin may have acted as vertical loadings in the initiation of lithospheric flexure. This hypothesis can be best expressed by coinciding gravity and topography highs, and the NE-SW trending axis is consistent with the prevailing NW-SE $\mathrm{S}_{\mathrm{Hmax}}$ orientation in this part of the continent.

\section{Conclusions}

This study attempts to explain the vertical motions of the Otway Ranges, SE Australia in terms of various modes of epeirogenic uplifts in intraplate setting. In the previous study (Shin, 2012), the uplift rates in the ranges and the surroundings have been estimated at $56.6 \pm 6.6 \mathrm{~m} \mathrm{Myr}^{-1}$ since the Quaternary and $43.8 \pm 4.6 \mathrm{~m} \mathrm{Myr}^{-1}$ since the past $5 \mathrm{Ma}$ from the stratigraphic relationship between the Quaternary marine terraces and Pliocene strandlines. Reactivation of pre-existing lithospheric structures driven by plate boundary forces is a main factor of the uplift in the study areas since, at least, the late Neogene in the current tectonic regime. The anomalously positive correlation between topography and gravity fields with the analysis of regional tectonic structure suggests possibly a lithospheric flexural deformation mode at order $10^{2} \mathrm{kms}$ in the region.

\section{References}

Abele, C., 1995, Eastern Otway Basin: The stratigraphy, structure, geophysics and hydrocarbon potential of the Eastern Otway Basin, Victoria. Geological Survey Report, 103, 75 p.

Beekman, F., Bull, J.M., Cloetingh, S., and Scrutton, R.A., 1996, Crustal fault reactivation facilitating lithospheric folding/buckling in the central Indian Ocean. Geological Society, London, Special Publications, 99, 251-263.

Burov, E.B., Lobkovsky, L.I., Cloetingh, S., and Nikishin, A.M., 1993, Continental lithospheric folding in Central Asia (II): Constraints from gravity and topography. 
Tectonophysics, 226, 73-87.

Cande, S.C. and Stock, J.M., 2004, Pacific-AntarcticAustralia motion and the formation of the Macquarie Plate. Geophysical Journal International, 157, 399-414.

Celerier, J., Sandiford, M., Hansen, D.L., and Quigley, M., 2005, Modes of active intraplate deformation, Flinders Ranges, Australia. Tectonics, 24, doi:10.1029/ 2004TC001679.

Cloetingh, S.A.P.L., Burov, E., Beekman, F., Andeweg, B., Andriessen, P.A.M., Garcia Castellanos, D., de Vicente, G., and Vegas, R., 2002, Lithospheric folding in Iberia. Tectonics, 21, 1041-1066.

Coblentz, D.D., Zhou, S., Hillis, R.R., Richardson, R.M., and Sandiford, M., 1998, Topography, boundary forces, and the Indo-Australian intraplate stress field. Journal of Geophysical Research, 103, 919-931.

Demidjuk, Z., Turner, S., Sandiford, M., George, R., Foden, J., and Etheridge, M., 2007, U-series isotope and geodynamic constraints on mantle melting processes beneath the newer volcanic province in South Australia. Earth and Planetary Science Letters, 261, doi:10.1016/ j.epsl.2007.07.006.

Dyksterhuis, S. and Müller, R.D., 2008, Cause and evolution of intraplate orogeny in Australia. Geology, $36,495-495$.

Finlayson, D.M., Johnstone, D.W., Owen, A.J., and WakeDyster, K.D., 1996, Deep seismic images and the tectonic framework of early rifting in the Otway Basin, Australian southern margin. Tectonophysics, 264, 137152.

Gerbault, M., 2000, At what stress is the central Indian Ocean lithosphere buckling? Earth and Planetary Science Letters, 178, 165-181.

Gurnis, M., Müller, R.D., and Moresi, L., 1998, Cretaceous vertical motion of Australia and the Australian Antarctic discordance. Science, 279, 1499-1504.

Huntley, D.J., Hutton, J.T., and Prescott, J.R., 1993, The stranded beach-dune sequences of south-east South Australia: A test of thermoluminescence dating, 0-800 ka. Quaternary Science Reviews, 12, 1-20.

Karner, G.D. and Watts, A.B., 1983, Gravity anomalies and flexure of the lithosphere at mountain ranges. Journal of Geophysical Research, 88, 10449-10477.

Kearey, P. and Vine, F.J., 1996, Global tectonics. Blackwell Science Ltd., Oxford, UK, 236 p.

McKenzie, D., Barnett, D.N., and Yuan, D.N., 2002, The relationship between Martian gravity and topography. Earth and Planetary Science Letters, 195, 1-16.

Musgrave, R. and Rawlinson, N., 2010, Linking the upper crust to the upper mantle: Comparison of teleseismic tomography with long-wavelength features of the gravity and magnetic fields of Southeastern Australia.
Exploration Geophysics, 41, 155-162.

Quigley, M., Cupper, M., and Sandiford, M., 2006, Quaternary faults of Southern Australia: Palaeoseismicity, slip rates and origin. Australian Journal of Earth Sciences, 53, 285-301.

Reynolds, S.D., Coblentz, D.D., and Hillis, R.R., 2002, Tectonic forces controlling the regional intraplate stress field in continental Australia: Results from new finiteelement modeling. Journal of Geophysical Research, 107, doi:10.1029/2001JB000408.

Sandiford, M., 2003a, Geomorphic constraints on the Late Neogene tectonics of the Otway Range, Victoria. Australian Journal of Earth Sciences, 50, 69-80.

Sandiford, M., 2003b, Neotectonics of Southeastern Australia: Linking the Quaternary faulting record with seismicity and in situ stress. In Hillis, R.R. and Muller, D. (eds.), Evolution and dynamics of the Australian Plate. Geological Society of Australia, Special Publication NY, USA, 101-113.

Sandiford, M. and Quigley, M., 2009, TOPO-OZ: Insights into the various modes of intraplate deformation in the Australian continent. Tectonophysics, 474, 405-416.

Sandiford, M., Quigley, M., de Broekert, P., and Jakica, S., 2009, Tectonic framework for the Cainozoic cratonic basins of Australia. Australian Journal of Earth Sciences, 56, doi:10.1080/08120090902870764.

Sandiford, M., Wallace, M., and Coblentz, D., 2004, Origin of the in situ stress field in south-eastern Australia. Basin Research, 16, 325-338.

Shin, J., 2012, Late Neogene and Quaternary vertical motions in the Otway coast, Southeast Australia (I): Development and geochronology of Quaternary marine terraces. Journal of the Korean Earth Sciences Society, 33, 519-533.

Smith, W.H.F. and Sandwell, D.T., 1997, Global sea floor topography from satellite altimetry and ship depth soundings. Science, 277, 1956-1962.

Sutherland, F.L., 2003, 'Boomerang' migratory intraplate Cenozoic volcanism, eastern Australian rift margins and the Indian-Pacific mantle boundary. Geological Society of America Special Papers, 372, 203-221.

Tickell, S.J., Edwards, J., and Abele, C., 1992, Port campbell embayment 1:100,000 map. Geological Survey of Victoria, Unpublished Report, 95 p.

Wallace, M.W., Dickinson, J.A., Moore, D.H., and Sandiford, M., 2005, Late Neogene strandlines of Southern Victoria: A unique record of eustacy and tectonics in Southeast Australia. Australian Journal of Earth Sciences, 52, 277-295.

2012년 8월 23일 접수 2012년 9월 26일 수정원고 접수 2012년 10월 13일 채택 